\title{
PROFIL KH. BAHAUDIN NUR SALIM (GUS BAHA) DAN PENGARUHNYA PADA GENERASI MILENIAL
}

Qowim Musthofa

IIQ An Nur Yogyakarta

$\triangle$ qowim@iiq-annur.ac.id

1. Pengantar

Nama Gus Baha, sapaan akrab KH. Bahauddin Nur Salim tidak asing bagi warga muslim di Indonesia. Popularitasnya di media sosial makin meningkat hingga banyak sekali masyarakat muslim yang menjadi pecinta (muhibbin) Gus Baha. Anggapan ini didasari oleh banyaknya riset dan artikel-artikel yang membahas tentang sosok Gus Baha, terdapat 2500 artikel yang menyebut nama Gus Baha berdasarkan pencarian di google cendekia pada tahun 2021. (Gus Baha - Google Cendekia, n.d.) Selain itu, di kanal Youtube, Gus Baha merupakan salah satu kiai milenial yang mempunyai jutaan penonton pada tahun 2020 (Rusydiyah et al., 2020)

Beberapa tulisan tersebut akan dipaparkan di sini sebagai referensi dan kajian literatur. Pertama skripsi yang ditulis oleh (Syarifah, 2020) yang membahas tentang tafsir audio visual di salah satu kanal youtube, sayangnya skripsi tersebut tidak menjelaskan secara rinci tentang biografi Gus Baha. Hal ini juga dilakukan oleh (Qudsy \& Muzakky, 2021) yang membahas tentang dinamika ngaji online Gus Baha di media sosial, namun dalam sisi pengungkapan biografi Gus Baha, tidak ditulis secara rinci. Selanjutnya skripsi yang ditulis oleh (Mahrita, 2021) yang mengungkap sisi penyampaian dalam kajian tafsir di media sosial.

Dari beberapa literatur yang sudah dilakukan oleh penulis sebelumnya, sebagian besar tidak menitikberatkan pembahasan profil Gus Baha secara lengkap dan detail. Mungkin para penulis sebelumnya memfokuskan risetnya di bidang yang lain, misalnya tentang kajian penafsiran dan akun-akun media sosial yang mengatasnamakan pecinta Gus Baha. Apalagi, Gus Baha secara

Oleh sebab itu, pada artikel biografi Gus Baha di sini, penulis menggunakan metode dokumentasi dan etnografi. Secara personal mungkin subyektif karena berdasarkan pengalaman selama mengikuti pengajian Gus Baha di Bedukan Wonokromo Bantul. Selain itu, metode wawancara juga dilakukan kepada beberapa santri dan muhibbin. Hal tersebut dilakukan sebagai bentuk konfirmasi dan penguat argumentasi dalam penulisan biografi ini. 
2. Nama dan Kelahiran

Gus Baha adalah panggilan akrabnya, nama lengkapnya adalah Bahauddin. Mayoritas artikel menyematkan nama ayahnya yaitu Nur Salim menjadi Bahauddin Nur Salim. Jadi nama aslinya adalah Bahauddin, sedangkan Nur Salim adalah nama ayahnya. Penulisan seperti ini lazim dilakukan pada sebagian besar nama tokoh yang hanya memiliki satu kata saja. Misalnya Maimoen, ditulis Maimoen Zubair sebab Zubair adalah ayah dari KH. Maimoen. Selain itu, mungkin karena keperluan administratif yang mewajibkan nama harus lebih dari satu kata.

Beberapa artikel menyebutkan tanggal dan tahun lahir Gus Baha secara berbeda, ada yang menuliskan 15 Maret 1970 (Qudsy \& Muzakky, 2021), sayangnya tidak menyertakan sumber yang jelas dari mana data tersebut diperoleh. Asumsi penulis, Qudsy mengutip Yahya, yang juga menulis pada tahun 1970 sebagai tahun lahir Gus Baha juga ditulis oleh (Yahya, n.d.), namun tanpa menyebutkan tanggal lahir.

Sumber lain menuliskan 29 September 1970. Ini yang paling banyak ditemukan di internet, situs Wikipedia misalnya, (Ahmad Bahauddin Nursalim Wikipedia Bahasa Indonesia, Ensiklopedia Bebas, n.d.) platform ensiklopedia bebas tersebut ditulis dan direvisi oleh penulis bebas di internet. Budi, (2020) pun menyebutkan 29 September 1970.

Dari perbedaan dua sumber di atas, yang lebih banyak menuliskan yang kedua, pendapat tersebut penulis konfirmasikan kepada Adib (2021) salah satu alumni pondok pesantren LP3IA menyebutkan bahwa yang benar adalah 29 September tahun 1970.

\section{Perjalanan Mencari Ilmu di Pesantren}

Gus Baha sewaktu kecil dididik secara langsung oleh ayahnya; KH. Nur Salim. Ayahnya merupakan seorang penghafal al-Qur'an murid dari KH. Abdullah Salam Kajen, Pati.

Gus Baha menghafal al-Qur'an di bawah bimbingan ayahnya sendiri. Setelah selesai menghafal al-Quran sambil mempelajari ilmu fikih. Adib (2021) menjelaskan bahwa Gus Baha tidak terlalu banyak menceritakan tentang proses menghafalkan Al-Qur'an tersebut, satu-satunya informasi yang bisa penulis dapatkan adalah setelah Gus Baha selesai menghafalkan Al-Qur'an lalu pergi ke Kudus di kawasan pemakaman Sunan Kudus.

Setelah di Kudus, Gus Baha dipondokkan oleh ayahnya di al-Anwar Sarang, sebuah pesantren berpengaruh di Jawa Tengah, yang diasuh oleh KH. Maimoen Zubair. Antara KH. Nur Salim dan KH. Maimoen Zubair mempunyai kedekatan 
emosional, mungkin hal tersebut yang melatarbelakangi KH. Nur Salim menitipkan anaknya kepada KH. Maimoen Zubair. Kesimpulan ini masih bisa diperdebatkan.

Secara keilmuan, Gus Baha terkenal sebagai pakar fikih. Hal ini didukung dengan pernyataan Gus Baha sendiri di dalam acara-acara seminar dan pengajiannya. Ia sering menceritakan tentang pengalamannya di pesantren alAnwar yang ketat dengan ngaji kitab-kitab fikih. Berdasarkan riset yang dilakukan oleh Rohman (2017) menjelaskan bahwa pembelajaran fikih dalam kurikulum pesantren al-Anwar mencapai $11.8 \%$, artinya fikih sangat mendominasi pemebelajaran di al-Anwar. Selain itu, pesantren al-Anwar juga memiliki kegiatan musyawarah yang diikuti oleh santri. Adapun kitab yang sering dijadikan sebagai referensi utama adalah fathu al-qarib, fathu al-mu'in dan al-mahalli. (Rohman, 2017: 192). Ketiga kitab tersebut banyak dijadikan rujukan utama di dalam pendidikan pesantren. Mungkin data tersebut berbeda dengan sewaktu Gus Baha mengaji di alAnwar, namun paling tidak menjadi gambaran bahwa pesantren al-Anwar memang mempunyai fokus yang lebih pada kluster ilmu fikih tersebut.

Setelah meninggalkan pesantren al-Anwar dan pulang mengembangkan ilmunya, ketenaran dalam bidang fikihnya itu bergeser. Bukan berarti Gus Baha tidak mengikuti perkembangan fikih, namun di tempat-tempat kajian yang digelar, menjadikannya terkenal dalam bidang tafsir al-Qur'an. Kepakaran Gus Baha di bidang tafsir tersebut, membuat pihak Universitas Islam Indonesia (UII) Yogyakarta meminta Gus Baha agar menjadi tim ahli di bidang tersebut. Oleh sebab itu, Gus Baha diberikan wewenang untuk menjadi tim tashih mushaf UII sekaligus menuliskan tafsir al-Quran.

Dari penjelasan di atas, dapat disimpulkan bahwa Gus Baha merupakan ulama yang lahir dari peradaban pesantren Indonesia, tanpa pernah mengenyam pendidikan formal di lembaga sekolah, apalagi hingga ke luar negeri. Gus Baha merupakan hasil dari pendidikan pesantren, yang kepkarannya diakui di lembagalembaga pendidikan formal.

\section{Sanad Keilmuan Gus Baha}

Gus Baha mempunyai dua guru yang paling berpengaruh di dalam meningkatkan kapasitas keilmuannya dalam hal fikih dan tafsir, yaitu KH. Nur Salim dan KH. Maimoen Zubair. Adapun dalam hal sanad ini, penulis menelusuri dari jalur KH. Maimoen Zubair. Situs Jigang (2020) menuliskan tentang sanad keilmuan Gus Baha hingga Nabi Muhammad melalui jalur dari KH. Maimoen Zubair. Berikut ini adalah sanad keilmuan Gus Baha hingga Nabi Muhammad:

1. KH. Bahauddin Nur Salim

2. KH. Maimoen Zubair 
3. Syaikh Yasin Padang

4. Syaikh Umar Hamdan

5. Syaikh Mahfudz Termas

6. Sayyid Abu Bakar bin Muhammad Syatha

7. Sayyid Ahmad bin Zaini Dahlan

8. Syaikh Utsman bin Hasan al-Dimyathi

9. Syaikh Ali al-Syanwani

10. Syaikh Isa bin Muhammad al-Barrowi

11. Syaikh Muhammad ad-Dafari

12. Syaikh Salim bin Abdillah al-Bashri

13. Syaikh Muhammad bin Alaudin al-Babili

14. Syaikh Syaikh Salim bin Muhammad as-Sanhuri

15. Syaikh Najm Muhammad bin Ahmad al-Ghaithi

16. Syaikh Zakariya al-Anshari

17. Syaikh Ibnu Hajar al-Atsqalani

18. Syaikh Ibrahim bin Ahmad at-Tanukhi

19. Syaikh Abul Abbas Ahman bin Abi Thalib al-Hajjar

20. Syaikh al Husain bin Al Mubarak az-Zabidi

21. Syaikh Abdul Awwal bin Isa as-Sijzi

22. Syaikh Abul Hasan Abdurrahman al-Muzaffar bin Dawud ad-Dawudi

23. Syaikh Abdullah bin Ahmad as-Sarakhsi

24. Syaikh Muhammad bin Yusuf bin Mathor al Firobi

25. Syaikh Imam Bukhari

26. Syaikh al-Humaidi Abdullah bin Zubair

27. Sufyan bin Uyainah

28. Yahya bin Sa'd al-Anshori

29. Muhammad bin Ibrahim at-Taimi

30. Alqamah bin Waqqash al-Laitsi

31. Umar bin Khattab

32. Rasulullah Muhammad Shallallahu alaihi Wasallam

Sanad keilmuan di atas berdasarkan proses pembelajaran dan pencarian ilmu Gus Baha melalui KH. Maimoen Zubair Sarang di pesantren al-Anwar. Situs Jigang (2020) tersebut menuliskan dari video dari Youtube (Sanad Keilmuan Gus Baha', Pantas Beliau Menjadi Orang Yang Sangat Alim // GUS RUM - YouTube, 2020) dengan argumentasi bahwa Gus Baha menjadi salah satu murid KH. Maimoen Zubair.

Hemat penulis, dimungkinkan sanad di atas hanya berdasarkan keilmuan secara umum, sebab di dalam tradisi pesantren memang mempunyai transmisi sanad yang ketat dibanding lembaga-lembaga keislaman yang lain. Oleh sebab itu, sanad 
keilmuan Gus Baha hingga Rasulullah di atas tidak bisa menjadi satu-satunya pedoman lalu menggeneralisir semua aspek bidang keilmuan Gus Baha.

Selain sanad keilmuan, Gus Baha merupakan hafal al-Quran (hamil al-quran), meskipun Gus Baha termasuk jarang sekali menceritakan tentang sanad al-Quran, namun secara silisilah sanad al-Quran, Gus Baha dididik sendiri oleh ayahnya yaitu KH. Nur Salim. Ayah Gus Baha merupakan murid dari KH. Abdullah Salam Kajen, Pati (Adib, 2021). Sedangkan KH. Abdullah Salam merupakan murid dari KH. Arwani Kudus, dan KH. Arwani Kudus adalah murid dari KH. Munawwir Krapyak Yogyakarta.

Dari silisah sanad al-Quran tersebut, mudah untuk disimpulkan bahwa secara sanad al-Quran, Gus Baha mempunyai otoritas dalam hal tersebut. Tidak heran jika Gus Baha sering menyampaikan kepada para jamaah ngaji bahwa beliau adalah penghafal al-Quran. Seingat penulis, Gus Baha sudah sedari kecil disuruh untuk menghafalkan surat-surat penting seperti Thaha, Yasin, as-Sajdah, al-Mulk, adDukhan, al-Kahfi dan juz 29 dan 30.

5. Karya-karya KH. Bahauddin Nur Salim

Gus Baha memiliki beberapa karya yang sudah diterbitkan, meliputi bidang bahasa Arab, ilmu qiraat dan tafsir al-Quran.

\subsection{Ringkasan kaidah Ilmu Qiraat}

Kitab berjudul Hifdzuna Li Hadza al-Mushaf merupakan ringkasan dari kitab alMuqni' karya Abu Amr Ad-Dani (Musthofa, 2014) artikel pada tahun 2014 tersebut menjelaskan tentang sekelumit kaidah penulisan al-Quran berdasarkan kaidah Abu Amr ad-Dani, salah satu mazhab penulisan rasm yang berpengaruh dalam sejarah Islam.

Hemat penulis, kitab al-Muqni' yang tebalnya mencapai 500-an halaman tersebut mampu diringkas secara sederhana dengan tabel-tabel untuk memudahkan pembaca adalah sebuah kelebihan. Kitab ini menggunakan bahasa Arab dengan tebal 69 halaman. Gus Baha meringkas kitab al-Muqni' karena terdapat kejanggalan-kejanggalan dalam penulisan al-Quran yang menggunakan rasm qiyasi, padahal penulisan al-Quran menggunakan rasm isthilahi ${ }^{1}$ (Nur Salim, n.d. h. 1). Hal ini dikarenakan al-Quran itu dibaca sesuai dengan riwayat secara mutawatir.

\footnotetext{
${ }^{1}$ Rasm qiyasi adalah penulisan secara imla' (dikte) yang ditulis sesuai dengan cara membacanya, sedangkan rasm istilahi merupakan karakteristik khusus yang dimiiki oleh metode penulisan al-Quran. Misalnya kata maliki dalam QS. Al-fatihah:3 ditulis tanpa menggunakan alif setelah huruf mim. Riwayat imam Hafs membacanya dengan panjang, sedangkan yang lainnya membaca pendek. (Ismail, n.d.) Gaya penulisan mushaf di Indonesia memang mempunyai dua ciri-ciri tersebut. Ada yang imla'i, ada pula yang istilahi.
} 


\subsection{Khazanah Andalusia}

Buku ini diterbitkan oleh penerbit Titian Ilahi Yogyakarta pada tahun 2005. Buku tersebut ditulis oleh Gus Baha dan Gus Wafi (putra KH. Maimoen Zubair). Menurut Nur Kholis (Komunikasi Pribadi, 2021) menjelaskan bahwa buku tersebut adalah hasil dari diskusi antara Gus Baha dan Gus Wafi ketika masih belajar bersama di Pesantren al-Anwar Sarang tentang ilmu nahwu. Ketika Gus Wafi hendak ke Yaman, buku tersebut menjadi hadiah dari Gus Baha kepada Gus Wafi.

Sebelumnya buku tersebut tidak laku, namun ketika tahun 2020, saat itu Gus Baha sedang viral di media sosial terutama Youtube, warganet berbondong-bondong mencari buku tersebut, sehingga buku Khazanah Andalus dicetak ulang pada tahun 2021.

Judul lengkap dari buku tersebut adalah 'Khazanah Andalus Menguak Karya Monumental Alfiyah Ibnu Malik'. Isi dari buku tersebut adalah tentang penjelasan dari bait-bait alfiyah ibnu Malik yang membahas tentang kaidah-kaidah nahwu yaitu tata bahasa dalam bahasa Arab.

\subsection{Tafsir al-Quran}

Tafsir al-Quran ini ditulis oleh Gus Baha sebagai tim ahli di UII Yogyakarta. Penulis tidak bisa memastikan terkait kapan tepatnya Gus Baha menjadi tim ahli, asumsi penulis mulai tahun 2004 atau 2005 ketika beliau berada di Yogyakarta. Sebab di tahun tersebut Gus Baha memang tinggal dan mukim di kawasan Bantul sebagaimana yang sudah dijelaskan sebelumnya. Terkait data ini mungkin bisa dilanjutkan oleh peneliti selanjutnya.

Tafsir al-Quran yang diterbitkan oleh tim lajnah al-Quran UII ini merupakan tafsir dengan metode tahlili. Penafsiran mulai dari juz pertama hingga juz terakhir dari alQuran. Tafsir ini berjumlah 10 jilid yang diterbitkan pada tahun 2018.

6. Membuat Majlis di Bantul Yogyakarta

Setelah menikah pada tahun 2003, tahun selanjutnya pada 2004 Gus Baha menyewa sebuah rumah di desa Pendowoharjo Sewon Bantul, beberapa kali Gus Baha pindah dari satu rumah kontrakan ke rumah lain. Konon, Gus Baha memang berniat untuk "sembunyi" (Rukhin, komunikasi Pribadi, 2020) Pada saat itu, sudah ada 2-3 santri yang ikut dengan Gus Baha di Bantul. Kisah yang diceritakan oleh Nur Kholis (2020) bahwa santri tersebut ada yang bertempat di pesantren An-Nur Ngrukem Yogyakarta. Rukhin (2020) menyebutkan bahwa pada saat itu yang ikut ngaji Gus Baha hanya beberapa orang saja, bahkan tidak sembarang orang bisa mengikuti ngaji, kecuali sudah disuruh Gus Baha untuk mengikutinya. Rukhin (2020) menceritakan bahwa ia harus sowan dulu dengan Gus Baha sebelum mengikuti ngaji. 
Tahun 2005, ketika KH. Nur Salim wafat, Gus Baha harus kembali ke Sedan, Rembang untuk menggantikan ayahnya mengasuh di pesantren LP3IA. Pesantren yang didirikan oleh ayahnya tersebut pada awalnya tidak memiliki nama secara kelembagaan, melainkan hanya dituliskan "Pesantren Kragan" dinisbatkan pada nama daerahnya yaitu Kragan, Narukan, Rembang.

Jadwal Ngaji Gus Baha yang mengatur adalah Gus Baha sendiri, namun biasanya dimulai pada hari Minggu terakhir di setiap bulan. Gus Baha mengirimkan pesan singkat kepada salah satu jamaahnya di Bantul, lalu jamaah tersebut menyebarkan pesan singkat tersebut kepada para jemaah. Penulis masih ingat ketika tahun 2009, disediakan blanko untuk menuliskan nama dan nomor telepon bagi yang ingin mendapatkan pemberitahuan ngaji Gus Baha di Bedukan Wonokromo Bantul.

Jadwal ngaji Gus Baha dimulai pada hari Minggu sore, biasanya pukul 16.00 WIB. selesai hingga maghrib, tergantung waktu maghribnya, namun bisa dipastikan durasinya lebih kurang 60 menit. Dilanjutkan malamnya pukul 20.00 WIB hingga selesai dengan ngaji kitab Tafsir al-Jalalain karya Imam Jalaluddin as-Suyuthi dan Imam Jalaluddin al-Mahalli. Pada hari senin biasanya Gus Baha ke kampus Universitas Islam Indonesia (UII) Yogyakarta, karena beliau sebagai salah satu tim ahli dalam bidang tafsir di kampus tersebut. Senin malamnya ngaji Tafsir jalalain lagi lalu hari selasa pagi pukul 06.00 WIB dilanjutkan ngaji kitab al-Hikam karya Ibnu Athaillah as-Sakandari. Setelah selesai, beliau bertolak pulang ke Rembang. Untuk lebih ringkasnya perhatikan tabel berikut ini:

Tabel 1. Jadwal pengajian Gus Baha di Bantul Yogyakarta

\begin{tabular}{|l|l|l|l|}
\hline NO & Hari & Waktu & Kajian \\
\hline 1 & Minggu & 16.00 WIB s.d selesai & $\begin{array}{l}\text { Kajian mengikuti salinan yang } \\
\text { diberikan oleh Gus Baha, pada tahun } \\
\text { 2014/2015 diganti kitab Nashaihul } \\
\text { Ibad }\end{array}$ \\
\hline 2 & Minggu & 20.00 WIB s.d selesai & Tafsir Jalalain \\
\hline 3 & Senin & 20.00 WIB s.d selesai & Tafsir Jalalain \\
\hline 4 & Selasa & 06.00 WIB s.d selesai & $\begin{array}{l}\text { Al-Hikam Ibn Athaillah setelah } \\
\text { khatam pada tahun 2014 diganti } \\
\text { dengan kitab Nashaihul Ibad. }\end{array}$ \\
\hline
\end{tabular}


Budi, (2020) menuliskan bahwa Gus Baha membuat di majlis di Bantul atas permintaan jamaah di Bantul, padahal tidak. Sebab jamaah di Bantul tidak berani untuk meminta secara langsung. Bahkan, untuk mengikuti kajian pun harus dengan izin Gus Baha. Rukhin (komunikasi pribadi, 2020) menceritakan bahwa ngaji di Bantul karena memang keinginan Gus Baha sendiri untuk melanjutkannya. Mungkin hal ini juga bertepatan dengan kesibukan Gus Baha yang diminta oleh pihak UII untuk menjadi ketua tim Lajnah Mushaf al-Quran.

Sebagaimana tabel di atas, pengajian Gus Baha di Bantul diadakan setiap bulan sekali, waktu yang ditentukan biasanya hari minggu terakhir di setiap bulannya. Dimulai pada hari minggu, senin dan selasa. Adapun waktunya adalah minggu sore, minggu malam, senin malam dan selasa pagi. Setelah selesai ngaji selasa pagi, Gus Baha pulang ke Rembang. Jadi kajian Gus Baha dilakukan empat kali dalam satu bulan.

Namun, sejak adanya pandemi Covid-19, bertepatan dengan jadwal ngaji bulan April 2019, kajian di Bantul diberhentikan untuk sementara, dan hingga tahun 2022 ini, belum dimulai lagi kajiannya yang berada di Bedukan, Wonokromo Bantul Yogyakarta. Justru kajian tersebut dilanjutkan di pesantren Lembaga Pembinaan Pendidikan dan Pengembangan Ilmu al-Quran (LP3IA) untuk pengajian tafsir yang sudah sampai pada surat az-Zumar pada bulan September 2021 (Nur Salim, 2021) Gus Baha menjelaskan bahwa jamaah dari Jogja tidak perlu ikut hadir "nggo alasan mbeling" (jadikan alasan saja untuk 'nakal'). Mungkin kajian di Bantul tidak dilanjutkan lagi, hal ini disebutkan oleh Rumanto (komunikasi pribadi, 2021) belum jelas apakah dilanjutkan di Bantul atau tetap di Narukan.

7. Pengaruh KH. Bahauddin Nur Salim bagi Masyarakat Muslim Indonesia Terkait pengaruh Gus Baha bagi masyarakat Muslim di Indonesia, penulis menyebarkan kuesioner yang telah diisi 150 responden berusia 17-35 tahun yang pernah dan rutin mendengarkan ceramah Gus Baha. Terdapat dua hal yang diperoleh dari kuesioner tersebut, pertama alasan menyukai pengajian Gus Baha, kedua pernyataan setelah mendengarkan ceramah Gus Baha.

Hasil dari sebaran kuesioner tersebut bisa dilihat pada diagram berikut 


\section{Hasil}

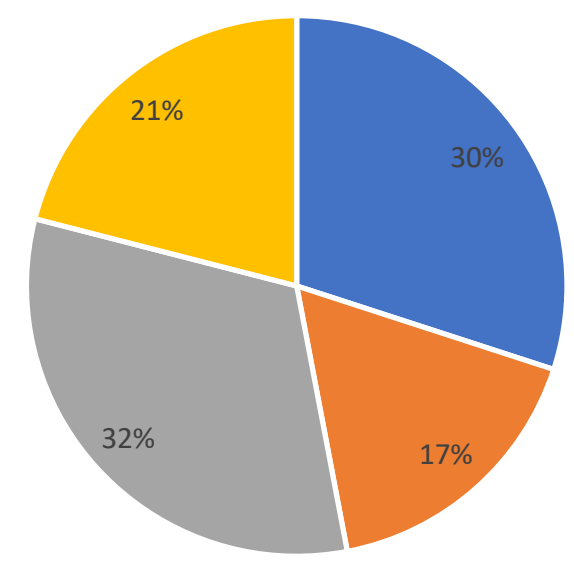

- Mudah Dipahami - Humoris $\square$ Alim/cerdas $\backsim$ Sederhana

Gambar 1. Hasil dari alasan mendengarkan ceramah Gus Baha

Data di atas menunjukkan bahwa alasan mendengarkan ceramah Gus Baha adalah karena mudah dipahami mencapai 32\%. Logika Gus Baha dalam menjelaskan sesuatu mendapatkan pengaruh yang lebih besar. Contoh saja dalam menjelaskan kalimat tauhid, alih-alih memberikan contoh yang sulit dengan gambaran-gambaran dzat dan sifat Allah yang rumit, Gus Baha memberikan analogi kebenaran tauhid dengan logika matematika, bilangan satu jika ditambah satu sama dengan dua, semua orang meyakini hal tersebut, baik orang ahli maksiat maupun yang paling taat kepada Allah. Oleh sebab itu kebenaran tersebut selayaknya diterima oleh siapapun yang mengucapkan hal tersebut. Begitu pula dengan kalimat tauhid, meskipun yang mengucapkan adalah orang yang maksiat, tetap saja tidak mengubah kebenaran tersebut.(Musthofa, 2017)

Selain kemudahan memahami ceramah Gus Baha, manfaat dari mendengarkan ceramah Gus Baha juga memberikan efek percaya diri dalam beragama sekaligus santai dalam berislam. Data di bawah ini menunjukkan bahwa 41\% mengaku setelah mendengarkan ceramah Gus Baha bisa memberikan efek santai dan percaya diri dalam berislam. 


\section{Pengaruh mendengarkan ceramah Gus Baha}

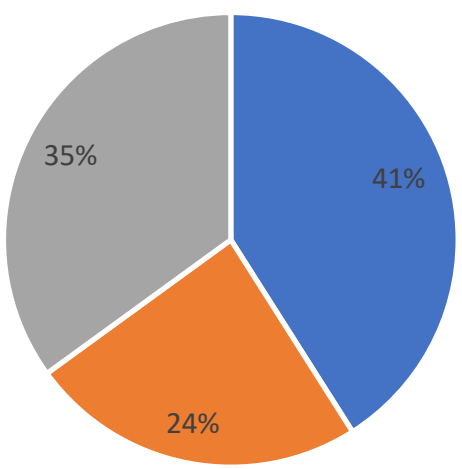

- Menjadi muslim yang santai dan percaya diri " Menjadi muslim yang berbahagia

- Menjadi muslim moderat dan toleran

Gambar 2. Hasil dari pengaruh mendengarkan ceramah Gus Baha

Dari hasil kuesioner di atas menunjukkan bahwa Gus Baha mempunyai pengaruh yang tidak bisa dikesampingkan dalam mewarnai corak Islam di Indonesia, oleh sebab itu hemat penulis, bahwa kajian-kajian tentang Gus Baha sebaiknya dikembangkan, apalagi Gus Baha memiliki keunikan dan ciri khas yang tidak dimiliki oleh pendakwah lainnya.

8. Simpulan

Dari uraian singkat tentang profil KH. Bahauddin Nur Salim di atas dapat disimpulkan bahwa pesantren masih mempunyai peran besar dalam pola pendidikan agama Islam di Indonesia. Meskipun masih terdapat kritikan-kritikan tentang pola pendidikan pesantren dengan metode bandongan dapat memupus daya kritis para santri (Farida \& Kasdi, 2021) namun hal itu tidak bisa dijadikan sebagai satu-satunya indikator. Sebaliknya, hal tersebut justru menjadi karakteristik pola pendidikan pesantren yang tidak dimiliki oleh lembaga formal dan konvensional.

Fenomena tentang Gus Baha merupakan bukti yang kuat bahwa pesantren masih memilki peran yang besar di masyarakat Indonesia. Kontribusinya bagi pembangunan karakter masyarakat Indonesia sangat besar untuk menjaga keutuhan persaudaraan Islam di Indonesia.

Daftar Pustaka

Ahmad Bahauddin Nursalim - Wikipedia bahasa Indonesia, ensiklopedia bebas. (n.d.).

Retrieved December 6, 2021, from

https://id.wikipedia.org/wiki/Ahmad_Bahauddin_Nursalim 
Budi. (2020). Biografi Gus Baha' (KH. Ahmad Bahauddin Nursalim). laduniid. https://www.laduni.id/post/read/66908/biografi-gus-baha-kh-ahmadbahauddin-nursalim

Farida, U., \& Kasdi, A. (2021). Women’s Roles in Ihyā' 'Ulūm al-Dīn and Method of Teaching it at Pesantrens in Indonesia. Al-Jami'ah: Journal of Islamic Studies, 59(1), 163-190. https://doi.org/10.14421/AJIS.2021.591.163-190

gus baha - Google Cendekia. (n.d.). Retrieved December 5, 2021, from https://scholar.google.com/scholar?hl=id\&as_sdt=0\%2C5\&q=gus+baha\&btn $\mathrm{G}=$

Ismail, S. M. (n.d.). Rasm al-Mushaf wa Dhabthuh baina at-Tauqif wa al-Isthilahat alHaditsah. Dar as-Salam.

Jigang. (2020). Sanad Keilmuan Gus Baha Hingga Rasulullah - JIGANG.ID. https://jigang.id/sanad-keilmuan-gus-baha-hingga-rasulullah/

Mahrita, E. (2021). Trend dan Metode Penyampaian Gus Baha`dalam Kajian Tafsir di Media Sosial.

Musthofa, Q. (2014, February). Upaya Menjaga Mushaf Kitab Karya Gus Baha qowim.net. https://www.qowim.net/2014/02/upaya-menjaga-mushafkita.html

Musthofa, Q. (2017). Tauhid versi Gus Baha; Penjelasan tentang Hadis Man Qala Lailahaillah - qowim.net. https://www.qowim.net/2017/03/tauhid-versi-gusbaha.html

Nur Salim, B. (n.d.). Hifdzuna Li Hadza al-Mushaf fi Bayan al-rasm al-utsmani wa Amtsilatih ma'a Dzikr Riwayat min Kitab al-Muqni. UII Press.

Nur Salim, B. (2021). NGAJI REBONAN // SURAT AZ-ZUMAR, AYAT 10 // 29 $\begin{array}{llll}\text { SEPTEMBER } & 2021 & \text { YouTube. }\end{array}$ https://www.youtube.com/watch?v=AgH-ao7g_9M

Qudsy, S. Z., \& Muzakky, A. H. (2021). Dinamika Ngaji Online Dalam Tagar Gus Baha: Studi Living Qur'an Di Media Sosial. POROS ONIM: Jurnal Sosial Keagamaan, 2(1), 1-19. https://doi.org/10.53491/POROSONIM.V2I1.48

Rohman, F. (2017). Pembelajaran Fiqih Berbasis Masalah melalui Kegiatan Musyawarah di Pondok Pesantren Al-Anwar Sarang Rembang. Al-Tadzkiyyah: Jurnal Pendidikan Islam, 8(2), 179-200. https://doi.org/10.24042/ATJPI.V8I2.2124 
Rusydiyah, E. F., Sa'diyah, H., \& Azizah, M. (2020). The Millenial Kiais. Epistemé: Jurnal Pengembangan Ilmu Keislaman, 15(1), 75-97. https://doi.org/10.21274/EPIS.2020.15.1.75-97

Sanad Keilmuan Gus Baha', Pantas Beliau Menjadi Orang yang sangat Alim // GUS RUM - YouTube.

(2020).

https://www.youtube.com/watch?v=J0qf90lBt3E\&t=25s

Syarifah, N. L. A. (2020). Tafsir Audiovisual: Kajian Penafsiran Gus Baha di Channel YouTube Al-Muhibbiin dan Implikasinya bagi Pemirsa [Institut Ilmu Al Quran (IIQ) Jakarta]. http://repository.iiq.ac.id//handle/123456789/1103

Yahya, I. D. (n.d.). Kisah Gus Baha: Nasab, Perkawinan hingga Karir Intelektual Alif.ID. Retrieved December 5, 2021, from https://alif.id/read/iip-dyahya/kisah-gus-baha-nasab-perkawinan-hingga-karir-intelektualnyab215367p/ 